\title{
A Green Analytical Procedure for Determination of Copper and Iron in Plant Materials after Cloud Point Extraction
}

\author{
Sidnei G. Silva, Pedro V. Oliveira and Fábio R. P. Rocha* \\ Instituto de Química, Universidade de São Paulo, Av. Prof. Lineu Prestes 748, \\ 05513-970 São Paulo-SP, Brazil
}

\begin{abstract}
Um procedimento analítico limpo baseado em extração em ponto nuvem é descrito para a determinação de cobre e ferro em materiais vegetais. Após a digestão da amostra em frascos fechados em forno de microondas, empregando mistura oxidante diluída $\left(\mathrm{HNO}_{3}+\mathrm{H}_{2} \mathrm{O}_{2}\right)$, os íons metálicos foram simultaneamente extraídos como complexos hidrofóbicos formados com 1,2-tiazolilazo-2-naftol (TAN) usando Triton X-114 como agente extrator. Íons cobre e ferro foram determinados por espectrometria de absorção atômica com chama (FAAS) e ferro também por espectrofotometria de absorção molecular UV-Vis. Nas medidas por FAAS, os limites de detecção (99,7\% de confiança) foram estimados em 1 e $10 \mu \mathrm{g} \mathrm{L}^{-1}$ para cobre e ferro, respectivamente. Respostas lineares para ambos os analitos foram observadas no intervalo de $25-200 \mu \mathrm{g} \mathrm{L}{ }^{-1}$. O fator de enriquecimento foi estimado em 30, com extração quantitativa dos complexos avaliada por medidas na solução sobrenadante remanescente após extração. Para a determinação de ferro por espectrofotometria UV-Vis, o limite de detecção (99,7\% de confiança) foi estimado em $1 \mu \mathrm{g} \mathrm{L}^{-1}$, com resposta linear entre 6 e $60 \mu \mathrm{g} \mathrm{L}^{-1}$. A exatidão do procedimento foi avaliada pela determinação dos metais em materiais de referência certificados e os resultados foram concordantes com os valores certificados no nível de confiança de $95 \%$. O consumo de reagentes foi de $1 \mathrm{~mL} \mathrm{HNO}_{3}$, $1,1 \mathrm{~mL} \mathrm{H} \mathrm{O}_{2}, 50 \mathrm{mg}$ Triton X-114 e $150 \mu \mathrm{g}$ TAN por determinação.
\end{abstract}

A green analytical procedure exploiting cloud point extraction for determination of copper and iron in plant materials is presented. After sample digestion with a diluted oxidant mixture $\left(\mathrm{HNO}_{3}+\right.$ $\mathrm{H}_{2} \mathrm{O}_{2}$ ) in a closed vessel microwave oven, metal ions were simultaneously extracted as hydrophobic complexes formed with 1,2-tiazolylazo-2-naphthol (TAN) using Triton X-114 as extracting agent. Copper and iron were determined by flame atomic absorption spectrometry (FAAS) and iron also by UV-Vis spectrophotometry. For FAAS, the detection limits ( $99.7 \%$ confidence level) were estimated as 1 and $10 \mu \mathrm{g} \mathrm{L}^{-1}$ for copper and iron, respectively. Linear responses for both analytes were observed in the $25-200 \mu \mathrm{g} \mathrm{L}^{-1}$ range. The enrichment factors were estimated as 30 for both analytes and the extraction was quantitative, as evaluated by measurements in the supernatant solution remaining after extraction. For iron determination by UV-Vis spectrophotometry, the detection limit was estimated as $1 \mu \mathrm{g} \mathrm{L}^{-1}$, with linear response within 6 and $60 \mu \mathrm{g} \mathrm{L}^{-1}$. The accuracy of the procedure was evaluated by determination of the metals in certified reference materials and the results agreed with the certified values at the $95 \%$ confidence level. In the whole procedure, the reagent consumption was $1 \mathrm{~mL} \mathrm{HNO}_{3}, 1.1 \mathrm{~mL} \mathrm{H}_{2} \mathrm{O}_{2}, 50 \mathrm{mg}$ Triton X-114 and $150 \mu \mathrm{g}$ TAN per determination.

Keywords: green analytical chemistry, cloud point extraction, FAAS, spectrophotometry, plant materials, copper, iron

\section{Introduction}

Copper and iron are important for plant nutrition, being classified as essential micronutrients and usually found in very low concentrations (2-50 and

*e-mail: frprocha@iq.usp.br
$20-600 \mu \mathrm{g} \mathrm{g}^{-1}$ respectively). Iron and copper are essential for chlorophyll synthesis and copper is present in diverse enzymes, acting in the metabolism of carbohydrates. On the other hand, high concentrations of these species may be toxic to plants. ${ }^{1}$ In view of these aspects, a large number of metal analyses in plant materials are required for agronomical studies. The assays are usually carried 
out from sample solutions obtained by time-consuming digestion procedures which consume large amounts of concentrated inorganic acids. ${ }^{2}$ Depending on the analytical technique employed for analysis, extraction and preconcentration can be required in view of the low analyte concentrations and the need for elimination of matrix effects and interfering species. Several procedures have been reported with this aim, including precipitation, liquid-liquid and solid-liquid extraction, ${ }^{3}$ which often generates large amounts of wastes. Alternative strategies, based on cloud point extraction, have been applied for separation and preconcentration of trace metals aiming determination in different sample matrices. ${ }^{4-6}$ The analytes are extracted into micelles after reaction with a hydrophobic complexing agent in the presence of a surfactant above the critical micelle concentration (CMC). ${ }^{7.8}$ In the process, aqueous solutions of non-ionic surfactants become turbid upon appropriate alteration of the physical-chemical conditions, usually by heating or introduction of suitable additives. The process results in a two-phase system: a surfactant-rich phase, which contains most of the surfactant and the extracted hydrophobic species and a phase containing a small amount of the surfactant, close to the critical micelle concentration. ${ }^{9}$ This approach presents several advantages in relation to conventional liquid-liquid extraction with organic solvents. The procedures are simpler and inexpensive, yielding high enrichment factors in a single extraction, because complexation and micelle formation occur in a single phase. In addition, cloud point extraction shows environmentally friendly characteristics by the substitution of toxic solvents ${ }^{6,10}$ by reduced amounts of low toxicity surfactants, in agreement with the green chemistry principles. ${ }^{11,12}$

Closed-vessel microwave-assisted acid digestion has been extensively used for sample preparation, including plant materials, ${ }^{13,14}$ replacing with advantages the acid digestion based on convective heating. Nitric acid is frequently employed for digestion of organic samples due to its safe manipulation, facility of purification and oxidative characteristics. ${ }^{15-17}$ Typically, $2-5 \mathrm{~mL}$ of nitric acid is sufficient for digestion of $200 \mathrm{mg}$ of sample, ${ }^{18,19}$ and $\mathrm{H}_{2} \mathrm{O}_{2}$ is generally used as an auxiliary oxidant agent. ${ }^{20}$ Excellent results also have been obtained by using diluted acids, ${ }^{2,13,14}$ yielding greener procedures by drastic reduction of the wastes for large scale analysis.

The aim of this work was the development of a green analytical procedure for determination of copper and iron in plant materials, exploiting microwave-assisted digestion with a diluted oxidant mixture and cloud point extraction with minimum reagent consumption.

\section{Experimental}

\section{Apparatus}

An AAS vario 6 atomic absorption spectrometer (Analytikjena, Jena, Germany) equipped with a deuterium lamp for background correction and hollow-cathode lamps as radiation sources was used for copper and iron absorbance measurements at 324.8 and $248.3 \mathrm{~nm}$, respectively. The instrumental parameters were adjusted according to the manufacturer's recommendations. An UV-Vis spectrophotometer (U-300, Hitachi, Tokyo, Japan) equipped with reduced volume plastic cells $(10 \mathrm{~mm}$ optical path) was employed for spectrophotometric measurements.

Acid decomposition was carried out in closed perfluoroalcoxy (PFA) vessels by using a microwave oven (Multiwave 3000, Anton Paar, Graz, Austria). A centrifuge (Q222T, Quimis, São Paulo, Brazil) was used to accelerate the phase separation in the cloud point extraction procedure.

A sliding-bar injector-commutator designed for flow injection analysis ${ }^{21}$ was employed to insert discrete volumes of the extracts in the FAAS nebulizer. A micropipette tip was connected in the position of the sample loop aiming microsample volume introduction. When the injector was moved to the injection position, the sample was aspirated to the nebulization chamber, yielding a transient signal. Measurements were based on peak height and carried out in triplicate.

\section{Reagents and solutions}

All solutions were prepared with analytical grade chemicals and deionized water. A $2.0 \times 10^{-3} \mathrm{~mol} \mathrm{~L}^{-1} \mathrm{TAN}$ stock solution was prepared by dissolving appropriate amounts of 1,2-tiazolylazo-2-naphthol (Across Organics, Pittsburgh, PA, USA) in ethanol. Solutions of the nonionic surfactant Triton X-114 (Sigma, St. Louis, MO, USA) were prepared at the $5 \%(\mathrm{~m} / \mathrm{v})$ concentration. Buffer solutions were prepared from acetic acid and sodium acetate or from hexamine and hydrochloric acid. Reference solutions were prepared by suitable dilutions of stocks $1000 \mathrm{mg} \mathrm{L}^{-1}$ solutions (Merck, Darmstadt, Germany).

\section{Microwave-assisted acid digestion procedure}

Crotalaria juncea, a plant often used as green manure, was employed to optimize the digestion procedure. Sample masses around $200 \mathrm{mg}$ were digested with different amounts of $65 \%(\mathrm{~m} / \mathrm{v}) \mathrm{HNO}_{3}, 30 \%(\mathrm{v} / \mathrm{v}) \mathrm{H}_{2} \mathrm{O}_{2}$ and water in PFA vessels. The heating program was performed in four steps: 1-ramp $\left(140{ }^{\circ} \mathrm{C} / 5 \mathrm{~min}\right) /$ hold $(1 \mathrm{~min})$; 2-ramp 
$\left(180{ }^{\circ} \mathrm{C} / 4 \mathrm{~min}\right) /$ hold $(5 \mathrm{~min}) ; 3$-ramp $\left(220^{\circ} \mathrm{C} / 4 \mathrm{~min}\right) /$ hold (10 min); 4-cooling to $25^{\circ} \mathrm{C}(20 \mathrm{~min})$.

\section{Cloud point extraction procedure}

The procedure was carried out in four steps: (i) $450 \mu \mathrm{L}$ of $2.0 \times 10^{-3} \mathrm{~mol} \mathrm{~L}^{-1} \mathrm{TAN}, 1 \mathrm{~mL}$ of $5 \%(\mathrm{~m} / \mathrm{v})$ Triton X-114, $1 \mathrm{~mL}$ of acetate buffer $1 \mathrm{~mol} \mathrm{~L}^{-1}(\mathrm{pH} 4.8)$ and $1 \mathrm{~mL}$ ascorbic acid $1 \%(\mathrm{~m} / \mathrm{v})$ were transferred to $15 \mathrm{~mL}$ graduate tubes containing suitable amounts of the sample or the reference solution, making up the volume to the mark with water; (ii) Phase separation was induced by heating the tubes in a water bath at $60^{\circ} \mathrm{C}$ for $15 \mathrm{~min}$. The mixture was then centrifuged for $20 \mathrm{~min}$ at $3000 \mathrm{rpm}$ (centrifugal force estimated as $700 \mathrm{x} \mathrm{g}$ ) and the aqueous phase was removed with a Pasteur pipette; (iii) The surfactant-rich phase showed a volume of ca. $300 \mu \mathrm{L}$ and was diluted with ethanol to $500 \mu \mathrm{L}$ by using the graduation in the flask, in order to decrease its viscosity, making feasible the transference to the measurement system; (iv) Measurements by UV-Vis spectrophotometry or by flame atomic absorption spectrophotometry were carried out. Aiming the determination of both analytes by FAAS in a single extract, $150 \mu \mathrm{L}$ of the extract were inserted in the FAAS nebulizer by the procedure previously described. The UV-Vis spectrophotometric measurement can be carried out with $c a .300 \mu \mathrm{L}$ of the extract by using the reduced volume cell.

For the analysis of plant materials, the acid digests were neutralized with $2.2 \mathrm{~mL}$ of $\mathrm{NaOH}\left(5 \mathrm{~mol} \mathrm{~L}^{-1}\right)$ before addition of the buffer solution.

\section{Results and Discussion}

\section{General aspects}

The chromogenic reagent 1,2-tiazolylazo-2-naphthol (TAN) has been mainly employed for liquid-liquid or solid-liquid extraction, yielding good selectivity and sensitivity in spectrometric determination of several metal ions. In view of its hydrophobic characteristics and reactivity with $\mathrm{Cu}(\mathrm{II})$ and $\mathrm{Fe}(\mathrm{II})$ ions, this reagent was selected for the cloud point extraction procedure..$^{22-24}$ Triton $\mathrm{X}-114\left(\mathrm{CMC}=3.5 \times 10^{-4} \mathrm{~mol} \mathrm{~L}^{-1}\right)$ was used as extracting agent in view of the highly convenient cloud point formation, in the $23-25^{\circ} \mathrm{C}$ range..$^{9}$ The absorption spectra of $\mathrm{Cu}(\mathrm{II})$ and $\mathrm{Fe}(\mathrm{II})$ complexes with TAN are shown in Figure 1. Both complexes have absorption maxima in the same spectral region, around $570 \mathrm{~nm}$, but iron complex shows also an absorption maximum at $787 \mathrm{~nm}$. In this wavelength, iron determination without spectral interference of other metal ions is possible.

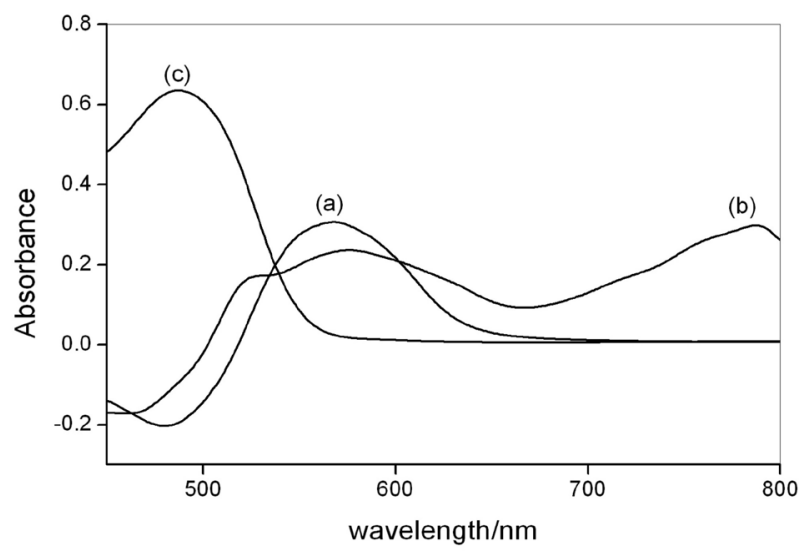

Figure 1. Absorption spectra of TAN complexes with (a) $\mathrm{Cu}$ (II) and (b) $\mathrm{Fe}(\mathrm{II})$; (c) absorption spectrum of the blank solution. Experimental conditions: $1 \mathrm{mg} \mathrm{L}^{-1} \mathrm{Cu}$ or $\mathrm{Fe}, 0.002 \% \mathrm{TAN}, \mathrm{pH}=6.0$ (hexamine buffer) and $0.02 \%$ Triton $\mathrm{X}-100$.

The effect of sample volume was evaluated by inserting discrete volumes in the FAAS nebulizer and the results were compared with those obtained by direct sample aspiration. Transient signals were obtained for discrete volumes and the peak heights were proportional to the metal ion amount. For a $150 \mu \mathrm{L}$ sample volume, the analytical signal achieved $82 \%$ of the steady state obtained by direct aspiration of the sample and the coefficient of variation was estimated as $1.2 \%(\mathrm{n}=10)$. This sample volume was then selected for further studies, which permits the determination of both analytes in the same extract.

\section{Optimization of the extraction procedure}

Optimization of the variables related to the extraction of the analytes was monitored by spectrophotometry, in order to maximize the extraction efficiency with minimum reagent consumption. The cloud point extraction of inorganic species is only slightly dependent of the $\mathrm{pH}$, but this variable critically affects complexation with TAN and thus the formation of hydrophobic species. Figure 2 shows the $\mathrm{pH}$ effect evaluated with hexamine buffer solutions and, for comparison, results obtained with an acetate buffer solution at $\mathrm{pH} 4.8$. The absorbance did not vary significantly up to $\mathrm{pH} 6.5$ for both analytes, being close to those obtained in the acetate buffer medium. In this way, acetate buffer $(\mathrm{pH}=4.8)$ was used in subsequent studies in order to minimize waste toxicity. The buffer concentration was maintained at minimum $\left(0.07 \mathrm{~mol} \mathrm{~L}^{-1}\right)$ in order to hinder the formation of acetate complexes with $\mathrm{Cu}$ (II) and $\mathrm{Fe}$ (III) $\left(\mathrm{K}_{\mathrm{f}}=4 \times 10^{2} \text { and } 5 \times 10^{9} \text {, respectively }\right)^{25}$ and also to reduce reagent consumption.

The effect of TAN concentration was evaluated for each analyte separately, aiming to establish the minimum reagent 


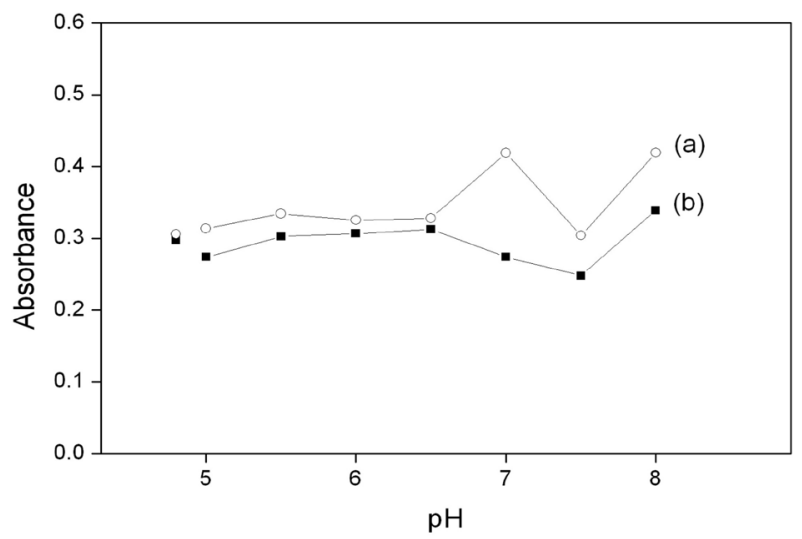

Figure 2. Effect of $\mathrm{pH}$ on the analytical signals, employing hexamine buffers $\left(0.05 \mathrm{~mol} \mathrm{~L}^{-1}\right)$ in $\mathrm{pH}$ ranging from 5.0 to 8.0 and acetate buffer $\left(0.05 \mathrm{~mol} \mathrm{~L}^{-1}\right), \mathrm{pH}=4.8$. TAN complexes formed with (a) $\mathrm{Cu}(\mathrm{II})$ and (b) $\mathrm{Fe}(\mathrm{II})$. Other experimental conditions as described in Figure 1.

concentration to yield maximum sensitivity. According to the results presented in Figure 3, $6.0 \times 10^{-5} \mathrm{~mol} \mathrm{~L}^{-1}$ TAN suffice to attain these goals. In these conditions, $150 \mu \mathrm{g}$ of TAN were consumed per determination, yielding in at least 16-fold molar excess in relation to the analytes. Measurements carried out by FAAS also indicated that concentrations higher than $6.0 \times 10^{-5} \mathrm{~mol} \mathrm{~L}^{-1}$ did not affect the analytical signal significantly.

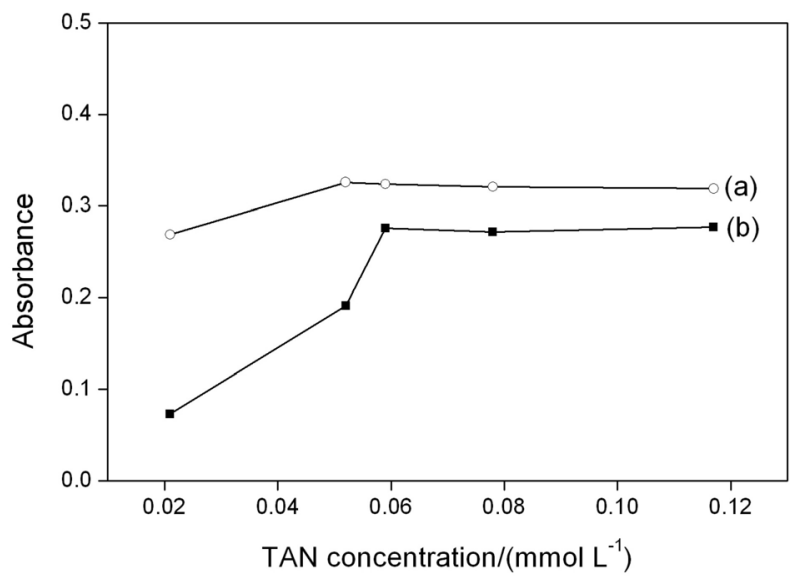

Figure 3. Effect of TAN concentration on the analytical signal of (a) $\mathrm{Cu}$ (II) and (b) $\mathrm{Fe}(\mathrm{II})$. Experimental conditions as described in Figure 1 with $\mathrm{pH}=4.8$ adjusted with acetate buffer.

In cloud point extraction procedures, the increase in surfactant concentration can decrease the analytical signal because of the increment in the surfactant-rich phase volume and the consequent dilution of the extract. However, this aspect was not relevant in the proposed procedure because the final volume was adjusted to $500 \mu \mathrm{L}$ before measurements. On the other hand, low surfactant concentrations can affect the extraction efficiency and thus the sensitivity, precision and accuracy of the procedure. Figure 4 shows the influence of Triton X-114 concentration in the extraction efficiency, monitored by UV-Vis spectrophotometry. Quantitative extraction of both analytes was observed for concentrations higher than $6 \times 10^{-3} \mathrm{~mol} \mathrm{~L}^{-1}$, which is at least 17 -fold higher than the CMC. ${ }^{10}$ Results agreed with those obtained by FAAS and this concentration was fixed for further studies.

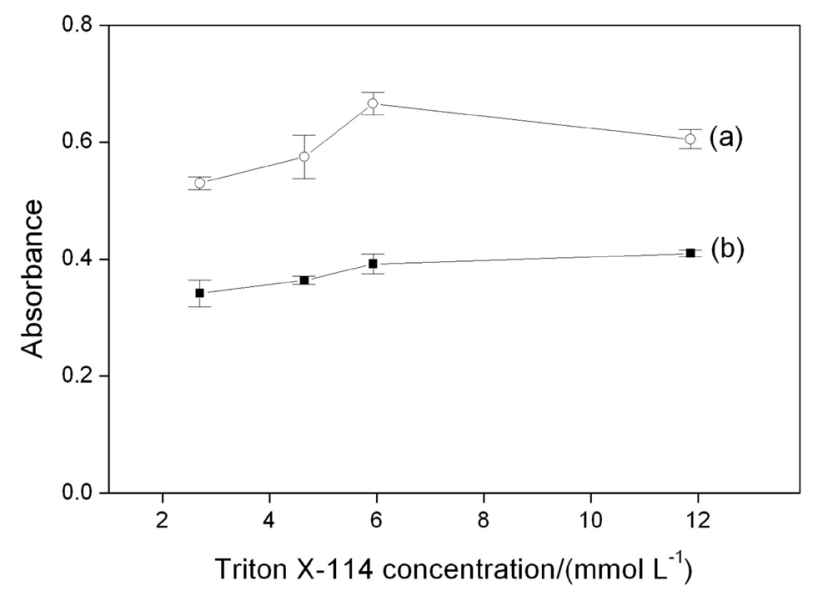

Figure 4. Effect of Triton X-114 concentration on the analytical signal for (a) $\mathrm{Cu}$ (II) and (b) $\mathrm{Fe}$ (II). Experimental conditions: $100 \mu \mathrm{g} \mathrm{L}^{-1} \mathrm{Cu}$ and $\mathrm{Fe}, 0.06 \mathrm{mmol} \mathrm{L}^{-1} \mathrm{TAN}$ and acetate buffer $(\mathrm{pH}=4.8)$.

\section{Microwave-assisted acid digestion}

Procedures for digestion of plant materials usually consume relatively large amounts of inorganic acids and hydrogen peroxide, and sometimes sample mass higher than $200 \mathrm{mg}$, even when closed-vessel microwaveassisted digestion is employed. ${ }^{2}$ Aiming minimizing waste generation also in the sample digestion, the concentrations of nitric acid and hydrogen peroxide in the microwaveassisted digestion procedure were optimized utilizing $250 \mathrm{mg}$ of Crotalaria juncea, and maintaining the final volume of $6.0 \mathrm{~mL}$ adjusted with water. When the acid volume was lower than $400 \mu \mathrm{L}$, the Crotalaria extracts presented solid residues and yellow color, indicating incomplete sample decomposition. Solid residues were avoided by increasing the acid amount and clear solutions were obtained by addition of $\mathrm{H}_{2} \mathrm{O}_{2}$. For Crotalaria samples, best results were obtained by using $500 \mu \mathrm{L}$ of $14 \mathrm{~mol} \mathrm{~L}^{-1}$ $\mathrm{HNO}_{3}$ and $1.1 \mathrm{~mL}$ of $30 \%(\mathrm{~m} / \mathrm{m}) \mathrm{H}_{2} \mathrm{O}_{2}$ for a sample mass of $250 \mathrm{mg}$. For a similar sample, the procedure proposed by Wu et al. ${ }^{26}$ consumes $500 \mathrm{mg}$ of sample, $5 \mathrm{~mL}$ of $14 \mathrm{~mol} \mathrm{~L}^{-1}$ $\mathrm{HNO}_{3}$ and $2 \mathrm{~mL}$ of $\mathrm{H}_{2} \mathrm{O}_{2}(30 \% \mathrm{~m} / \mathrm{m})$ per determination.

After sample digestion, the remaining excess of acid was neutralized with a $\mathrm{NaOH}$ solution and the $\mathrm{pH}$ was further adjusted with an acetate buffer solution $(\mathrm{pH}=4.8)$ for cloud point extraction. 


\section{Effect of concomitant species}

The effects of concomitant species on the determination of $25 \mu \mathrm{g} \mathrm{L}{ }^{-1} \mathrm{Cu}$ (II) or $100 \mu \mathrm{g} \mathrm{L}^{-1} \mathrm{Fe}$ (III) were studied by measurements using both UV-Vis spectrophotometry and FAAS. It was considered interference when species caused variations higher than $\pm 5 \%$ in the analytical signal. The evaluated concentrations of the concomitants were based on the maxima concentration in some certified reference materials: Apple leaves SRM 1515, Peach leaves SRM 1547, Tomato leaves SRM 1573a (from NIST) and Citrus leaves 1572 (from NBS). The results of the interference studies are shown in Table 1.

Table 1. Effect of concomitant species on the determination of $25 \mu \mathrm{g} \mathrm{L}$ copper and $100 \mu \mathrm{g} \mathrm{L}^{-1}$ iron after cloud point extraction

\begin{tabular}{lccccc}
\hline & & \multicolumn{4}{c}{ Signal variation (\%) } \\
\cline { 3 - 6 } Species & $\begin{array}{c}\text { Concentration } \\
\left(\mu \mathrm{g} \mathrm{L}^{-1}\right)^{\mathrm{a}}\end{array}$ & \multicolumn{2}{c}{ FAAS } & \multicolumn{3}{c}{$\begin{array}{c}\text { UV-Vis } \\
\text { spectrophotometry }\end{array}$} \\
\cline { 3 - 6 } & & $\mathrm{Cu}$ & $\mathrm{Fe}$ & $\mathrm{Cu}$ & $\mathrm{Fe}$ \\
\hline $\mathrm{Al}^{3+}$ & $9 \times 10^{3}$ & -2.2 & -0.1 & -3.7 & -2.9 \\
$\mathrm{Ca}^{2+}$ & $8 \times 10^{5}$ & -3.8 & +4.9 & +0.1 & +4.2 \\
$\mathrm{Cd}^{2+}$ & 25 & -1.9 & -1.5 & -1.2 & +4.4 \\
$\mathrm{Co}^{2+}$ & 9 & +4.9 & -1.3 & -1.1 & +0.3 \\
$\mathrm{Fe}^{3+}$ & $6 \times 10^{3}$ & +3.7 & - & +252 & - \\
$\mathrm{Hg}^{2+}$ & 0.7 & +3.4 & +0.7 & +2.6 & +0.7 \\
$\mathrm{Mg}^{2+}$ & $2 \times 10^{4}$ & +0.3 & -2.4 & -2.7 & -2.4 \\
$\mathrm{Mn}^{2+}$ & $4 \times 10^{3}$ & +1.2 & -0.8 & +6.2 & -0.1 \\
$\mathrm{Ni}^{2+}$ & 26 & +4.9 & +3.0 & +85.1 & +3.0 \\
$\mathrm{PO}_{4}^{3-}$ & $1 \times 10^{4}$ & +4.8 & -4.7 & +4.3 & -4.7 \\
$\mathrm{~Pb}^{2+}$ & 14 & +1.8 & -4.2 & +3.3 & -3.8 \\
$\mathrm{VO}^{2+}$ & 14 & -1.5 & +1.7 & -2.5 & +1.7 \\
$\mathrm{Zn}^{2+}$ & 500 & +3.8 & -1.7 & +27.1 & -1.7 \\
$\mathrm{Cu}^{2+}$ & 95 & - & -3.7 & - & +0.6 \\
\hline
\end{tabular}

aestablished by the maximum concentration found in digests of plant certified reference materials.

TAN forms stable complexes with various metal ions and copper determination by UV-Vis spectrophotometry was not possible due to spectral interferences. Several TAN complexes formed with species present in digests of plant materials, such as $\mathrm{Fe}(\mathrm{II}), \mathrm{Zn}$ (II) and $\mathrm{Mn}$ (II), absorb in the same spectral region of the $\mathrm{Cu}$ (II) complexes. ${ }^{24}$ The main interference was observed in the presence of $\mathrm{Fe}(\mathrm{III})$, which caused a positive error of $252 \%$ on copper determination. The effect of several masking agents, such as EDTA, fluorite and phosphate, was evaluated but it was not possible to eliminate the interferences due to the high formation constant of the corresponding TAN complexes.
The concomitant species did not present significant interferences on iron determination by spectrophotometric measurements at $787 \mathrm{~nm}$. In view of the inherently high selectivity provided by FAAS, significant interferences may be attributed only to the preconcentration step, because cations that react with TAN may decrease the extraction efficiency of the analytes. However, for all the species evaluated the signal variation was lower than $5 \%$ (Table 1).

\section{Analytical features and application}

Calibration curves were obtained by preconcentration of $15 \mathrm{~mL}$ of reference solutions under the optimized conditions for cloud point extraction. The detection limits (99.7\% confidence level) estimated by FAAS according to IUPAC recommendations ${ }^{27}$ were $1 \mu \mathrm{g} \mathrm{L}^{-1}$ copper and $10 \mu \mathrm{g} \mathrm{L}^{-1}$ iron, with linear responses in the $25-200 \mu \mathrm{g} \mathrm{L}^{-1}$ range. The calibration curves can be described by the equations: $\mathrm{A}=0.0028 \mathrm{C}\left(\mu \mathrm{g} \mathrm{L}^{-1}\right)+0.0150(\mathrm{r}=0.999)$ for copper and $\mathrm{A}=0.0051 \mathrm{C}\left(\mu \mathrm{g} \mathrm{L}^{-1}\right)+0.0644(\mathrm{r}=0.996)$ for iron. The enrichment factors were estimated as 30 , in agreement with the theoretical value, indicating quantitative extraction. This was confirmed by measurements in the supernatant solution after extraction. For iron determination by UV-Vis spectrophotometry, the detection limit was estimated as $1 \mu \mathrm{g} \mathrm{L}^{-1}$ (99.7\% confidence level), with linear response in the 6-60 $\mathrm{g} \mathrm{L} \mathrm{L}^{-1}$ range. The apparent molar absorptivity was estimated as $3.0 \times 10^{5} \mathrm{~L} \mathrm{~mol}^{-1} \mathrm{~cm}^{-1}$ (at $787 \mathrm{~nm}$ ), which is 17 -fold higher than the achieved in the spectrophotometric procedure proposed by Ferreira and Nano. ${ }^{24}$ The reagent consumption was estimated as $50 \mathrm{mg}$ Triton X-114 and $150 \mu \mathrm{g}$ TAN per determination. For comparison, an analytical procedure involving solvent extraction consumed $10 \mathrm{~mL}$ of benzene per determination. ${ }^{28}$

The reliability of the developed procedure was evaluated through the analysis of plant certified reference materials. The results obtained by UV-Vis spectrophotometry and FAAS are depicted in Tables 2 and 3, respectively. All results were in agreement with certified values at the $95 \%$ confidence level.

Table 2. Determination of Fe in certified reference materials (CRM) by UV-Vis spectrophotometry after cloud point extraction

\begin{tabular}{lcc}
\hline CRM & \multicolumn{2}{c}{ Fe $\left(\mu \mathrm{g} \mathrm{g}^{-1}\right)$} \\
\cline { 2 - 3 } & Certified value & Proposed Method \\
\hline Peach Leaves NIST 1547 & $218 \pm 14$ & $209 \pm 21$ \\
Tomato Leaves NIST 1573a & $368 \pm 7$ & $356 \pm 6$ \\
Apple Leaves NIST 1515 & $83 \pm 5$ & $81 \pm 1$ \\
Citrus Leaves NBS 1572 & $90 \pm 10$ & $93 \pm 9$ \\
\hline
\end{tabular}


Table 3. Determination of $\mathrm{Cu}$ and Fe in certified reference materials (CRM) by FAAS after cloud point extraction

\begin{tabular}{|c|c|c|c|c|}
\hline \multirow[t]{2}{*}{ CRM } & \multicolumn{2}{|c|}{$\mathrm{Cu}\left(\mu \mathrm{g} \mathrm{g}^{-1}\right)$} & \multicolumn{2}{|c|}{$\mathrm{Fe}\left(\mu \mathrm{g} \mathrm{g}^{-1}\right)$} \\
\hline & Certified value & Proposed methodology & Certified value & Proposed Methodology \\
\hline Peach Leaves NIST 1547 & - & - & $218 \pm 14$ & $210 \pm 3$ \\
\hline Tomato Leaves NIST 1573a & $4.70 \pm 0.14$ & $4.69 \pm 0.19$ & $368 \pm 7$ & $376 \pm 6$ \\
\hline Apple Leaves NIST 1515 & $5.64 \pm 0.24$ & $5.56 \pm 0.12$ & $83 \pm 5$ & $84 \pm 1$ \\
\hline Citrus Leaves NBS 1572 & - & - & $90 \pm 10$ & $96 \pm 2$ \\
\hline
\end{tabular}

\section{Conclusions}

An accurate and precise green analytical procedure was developed for copper and iron determination in plant materials, based on digestion with a diluted oxidant mixture and cloud point extraction. Minimization of reagent consumption for sample pretreatment and the extraction with surfactant reduced significantly the waste generation and toxicity. Copper determination by UV-Vis spectrophotometry was not feasible in view of spectral interferences caused by metal ions present in the sample matrix that form complexes with TAN, mainly Fe(III). However, spectrophotometric determination of iron can be carried out without interferences because the iron complex present an absorption maxima in a spectral region in which the others complexes did not absorb radiation. Copper and iron were properly determined by FAAS using small sample aliquots $(150 \mu \mathrm{L})$ for nebulization, achieving $82 \%$ of the steady state signal.

\section{Acknowledgements}

The authors acknowledge the fellowships and financial support from Conselho Nacional de Desenvolvimento Científico e Tecnológico (CNPq) and Fundação de Amparo à Pesquisa do Estado de São Paulo (FAPESP).

\section{References}

1. Epstein, E.; Bloom, A. J.; Mineral Nutrition of Plants: Principles and Perspectives; $2^{\text {nd }}$ ed., Sinauer Associates: California, 2005.

2. Maruchi, A. K.; Rocha, F. R. P.; Microchem. J. 2006, 82, 207.

3. Rocha, F. R. P.; Teixeira, L. S. G.; Quim. Nova 2004, $27,807$.

4. Ghaedi, M.; Fathi, M.R.; Shokrollahi, A.; Gharaghani, S.; Ahmadi, F.; Soylak, M.; Quim. Nova 2008, 31, 70.

5. Candir, S.; Narin, I.; Soylak, M.; Talanta 2008, 77, 289.

6. Bezerra, M. D.; Arruda, M. A. Z.; Ferreira, S. L. C.; J. Appl. Spectrosc. 2005, 40, 269.

7. Quina, F. H.; Hinze, W. L.; Ind. Eng. Chem. Res. 1999, 38, 4150 .

8. Silva, M. F.; Cerutti, E. S.; Martinez, L. D.; Microchim. Acta 2006, 155, 349.
9. Paleologos, E. K.; Stalikas, C. D.; Tzouwara-Karayanni, S. M.; Karayannis, M. I.; Anal. Chim. Acta 2001, 436, 49.

10. Hinze, W. L.; Pramauro, E.; Crit. Rev. Anal. Chem. 1993, 24, 133.

11. Anastas, P. T.; Kirchhoff, M. M.; Acc. Chem. Res. 2002, 35, 686.

12. Rocha, F. R. P.; Nóbrega J. A.; Fatibello-Filho, O.; Green Chem. 2001, 3, 216.

13. Esslemont, G.; Maher, W.; Ford, P; Krikowa, F.; At. Spectrosc. 2000, 21, 42 .

14. Araújo, G. C. L.; Gonzalez, M. H.; Ferreira, A. G.; Nogueira, A. R. A.; Nóbrega, J.A; Spectrochim. Acta, Part B 2002, 57, 2121.

15. Würfels, M.; Jackwerth, E.; Fresenius J. Anal. Chem. 1985, 322,345 .

16. Würfels, M.; Jackwerth, E.; Stoeppler, M.; Fresenius J. Anal. Chem. 1987, 329, 459.

17. Kubrakova, I. V.; Formanovskii, A. A.; Kudinova, T. F.; Kuz'min, N. M.; J. Anal. Chem. 1999, 54, 460.

18. Koltz, L.; Henze, G.; Kaiser, G.; Pahlke, S.; Veber, M.; Tölg, G.; Talanta 1979, 26, 681.

19. Stoeppler, M.; Müller, K.P.; Backhaus, F.; J. Anal. Chem. 1979, 276, 107.

20. Wu, S. L.; Feng, X. B.; Wittmeier, A.; J. Anal. At. Spectrom. 1997, 12, 797.

21. Bergamin-Filho, H.; Medeiros, J. X.; Reis, B. F.; Zagatto, E. A. G.; Anal. Chim. Acta 1978, 101, 9.

22. Lemos, V. A.; Santos, E. S.; Santos, M. S.; Yamaki, R. T.; Microchim. Acta 2007, 158, 189.

23. Anderson, R. G.; Nickless, G.; Analyst 1967, 92, 1093.

24. Ferreira, S. L. C.; Nano, R. M. W.; Talanta 1994, 41, 1937.

25. Harris, D. C.; Quantitative Chemical Analysis, $7^{\text {th }}$ ed., W.H. Freeman and Co: New York, 2007.

26. Wu, S.; Feng, X.; Wittmeier, A.; J. Anal. At. Spectrom. 1997, $12,797$.

27. http://www.iupac.org/goldbook/L03540.pdf, accessed in December 2008.

28. Otomo, M.; Watanabe, T.; Moriya, M.; Anal. Sci. 1986, 2, 549.

Received: March 12, 2009

Web Release Date: November 12, 2009

FAPESP helped in meeting the publication costs of this article. 